\title{
Erector spinae plane block in breast surgery
}

\section{To the Editor}

Having read carefully the original article by Swisher et al on the analgesic effectiveness of erector spinae plane block compared with paravertebral block in breast surgery, ${ }^{1}$ we make few comments regarding (1) the study design, (2) the time point of pain assessment and (3) the pain management protocol.

1. The non-inferior margin is crucial for sample size calculation in a noninferior study design. In this study, a score of 1.25 and $2 \mathrm{mg}$ morphine were used as the margin of pain score and opioid consumption, respectively. However, only the former value has been proven to have a clinically important difference. ${ }^{2}$ Would the authors provide some evidence about the margin of opioid consumption? Would a difference of $2 \mathrm{mg}$ morphine really have meaningful values clinically?

2. One of the primary endpoints was the Numeric Rating Scale (NRS) pain score in postanesthesia care unit (PACU), but the exact time point for pain assessment was not indicated. How long was the time interval for patients staying in PACU? Because the pain score will likely decrease after opioid therapy, it is necessary to evaluate pain intensity at a predefined time point. Moreover, was the pain score assessed at rest or with movement? These issues should also be mentioned.

3. It was reported that a standard PACU opioid algorithm was used in this study, but we are confused about the description intravenous fentanyl $25 \mu \mathrm{g}$ for NRS pain scores of less than 5 ' and 'oxycodone $5 \mathrm{mg}$ for NRS of 4-6'. What was the target NRS pain score you allowed: 4 or 5 ? Why is an NRS pain score of 4-6 suitable for oxycodone usage? Would any opioids be given if the NRS pain score is 3 or below and what kind of opioids should be used?

We sincerely hope the authors can provide further explanations of these points to make their results clearer and more compelling.

Xue Li, Zhen-Zhen Xu

Peking University First Hospital, 100034 Beijing, China

Correspondence to Dr Xue Li, Peking University First Hospital, 100034 Beijing, China; 3999165@163. com

Contributors XL drafted the manuscript and Z-ZX revised it. 
Funding The authors have not declared a specific grant for this research from any funding agency in the public, commercial or not-for-profit sectors.

Competing interests None declared.

Patient consent for publication Not required.

Provenance and peer review Not commissioned; internally peer reviewed.

\section{(2) \\ OPEN ACCESS}

Open access This is an open access article distributed in accordance with the Creative Commons Attribution Non Commercial (CC BY-NC 4.0) license, which permits others to distribute, remix, adapt, build upon this work non-commercially, and license their derivative works on different terms, provided the original work is properly cited, an indication of whether changes were made, and the use is non-commercial. See: http:// creativecommons.org/licenses/by-nc/4.0/.

(C) American Society of Regional Anesthesia \& Pain Medicine 2021. Re-use permitted under CC BY-NC. No commercial re-use. Published by BMJ.

\section{Check for updates}

To cite Li X, Xu Z-Z. Reg Anesth Pain Med

2021;46:189-190.

Received 26 March 2020

Revised 18 April 2020

Accepted 22 April 2020

Published Online First 28 May 2020

\section{SLinked}

- http://dx.doi.org/10.1136/rapm-2020-101647

Reg Anesth Pain Med 2021;46:189-190.

doi:10.1136/rapm-2020-101497

\section{REFERENCES}

1 Swisher MW, Wallace AM, Sztain JF, et al. Erector spinae plane versus paravertebral nerve blocks for postoperative analgesia after breast surgery: a randomized clinical trial. Reg Anesth Pain Med 2020;45:260-6.

2 Myles PS, Myles DB, Galagher W, et al. Measuring acute postoperative pain using the visual analog scale: the minimal clinically important difference and patient acceptable symptom state. $\mathrm{Br} J$ Anaesth 2017;118:424-9. 